\title{
Alterations in lipids and minerals in relation to larval trematode infections of Nerita polita marine snails
}

\author{
A. H. HASSAN ${ }^{1,4 *}$, N. S. ALHAZMI ${ }^{2}$, A. AR. FILIMBAN ${ }^{1}$, M. N. ALSULAMI ${ }^{3}$ \\ 1Biology Department, College of Sciences, King Abdulaziz University, Jeddah, Saudi Arabia *E-mail: ahhassan1@kau.edu.sa; \\ ${ }^{2}$ Biology Department, College of Applied Sciences, Umm Al-Qura University, Makkah, Saudi Arabia; ${ }^{3 B}$ Biology Department, College of

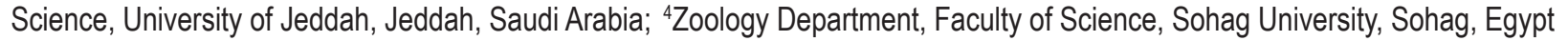

Article info

Received December 2, 2020

Accepted September 30, 2021

\section{Summary}

Marine snails provide an important source of vitamins, proteins, minerals, and essential fatty acids, and their mucus has a therapeutic significance. Parasitic infection of larval trematodes in these snails affects their nutritional value. The present study aimed to screen Nerita polita marine snails for the prevalence of cercarial infections and to evaluate the changes in lipids and some minerals in the infected as well as non-infected ones. Snails were collected randomly from February 2018 to January 2019 from the Red Sea Obhor bay, Jeddah city, Saudi Arabia. The amount of triglycerides, cholesterol, and phospholipids in the Digestive Gland Gonad Complex (DGG), hemolymph, and Snail Conditioned Water (SCW) of non-infected and infected Nerita polita snail was estimated using a spectrophotometer. Minerals content such as $\mathrm{Ca}, \mathrm{Zn}, \mathrm{Pb}, \mathrm{Na}, \mathrm{Mn}, \mathrm{Mg}, \mathrm{K}, \mathrm{Fe}, \mathrm{Cu}$, and $\mathrm{Cd}$, in the DGG and shell in the infected and non-infected snails were analyzed using an Inductively Coupled Plasma Optical Emission Spectrometer (ICP-OES). Two types of cercariae were detected, ocellate furcocercus cercaria (Trichobilharzia regent) and xiphidiocercaria (Litorina saxatilis VII). The study showed that there is a fluctuation in the concentration of lipids and minerals between increase and decrease in DGG, hemolymph, shell, and SCW in infected snails. The nutritive value of the snails is affected with infection through the decrease of some lipids and minerals in infected snails. Further qualitative studies are needed.

Keywords: Nerita; triglycerides; cholesterol; phospholipids; minerals; cercariae

\section{Introduction}

Marine snails are known to have a high nutritive value, they have a great percent of polyunsaturated fatty acids which are needed for human fitness. Marine snail's flesh has a great value in nutrition as a source of lipids, and minerals (Alves et al., 2014). They constitute a major part of the trematode's life cycle as the first and second intermediate hosts for trematode parasites. These parasites are transmitted to marine fish and marine vertebrates. Trematode parasites have a complicated life cycle as they need the snails as intermediate hosts for transformation into the infective stage i.e. cercariae. In the first intermediate host, sporocysts are consisted and get their nutritional needs through their tegument and develop into rediae containing cercariae inside the snail host. Cercariae have a wide range of shapes and features. They are modified physiologically and behaviorally to find and penetrate their final hosts (Toledo et al., 2014; Hassan et al., 2018a; Al-Solami et al., 2019; Turkistani et al., 2021).

Marine snails comprise a high nutritional value including vitamins, proteins, minerals, and essential fatty acids. Concerning lipids,

\footnotetext{
* - corresponding author
} 
they play important functions in the energy and structure of biological systems and animal's survival under physiological stress like low food supply, parasites that need lipid consumption after depletion of the carbohydrates which lead to changes in lipids structure. Lipids are a major constituent in the biological membranes and any change in the metabolic state of the snail as response to stress may influence the number and structure of these lipids (Stuart et al., 1998; Storey, 2002; Giokas et al., 2005; Bandstra et al., 2006; Ab Lah, et al., 2017).

Snail's mucus was found to be consist of a complicated mixture of proteoglycans, glycosaminoglycans, glycoprotein enzymes, hyaluronic acid, copper peptides, antimicrobial peptides, and metal ions (Smith et al., 2009). It contains primarily allantoin, collagen, elastin, and glycolic acid (Thomas, 2013). Many studies have dealt with the peptide constituent of snail's mucus-like mucin which contains both Gram-positive and Gram-negative antibacterial activity which stimulates some components of the immune system including barrier repair and inflammatory cell recruitment (Thomas, 2013; Etim et al., 2016). Another study showed that snail mucus is beneficial in bone repairing and teeth regeneration due to its ability to increase the osteopontin expression and stimulate the expression of some inflammatory genes in the cells of the dental pulp (Kantawong et al., 2016). It can also be useful to decline pigmentation scarring-and wrinkles. Furthermore, it can assist wound healing and stop its infections (Adikwu \& Alozie, 2007; Adikwu \& Enebeke, 2007).

Studies dealt with marine host-parasite systems remain scarce. The present study aimed to investigate the effect of larval trematode infections on the content of lipids and minerals in infected snails' Digestive Gland- Gonad complex (DGG), hemolymph, and Snail-Conditioned Water (SCW) as well as uninfected ones.

\section{Materials and Methods}

\section{Collection of snails}

Marine snails were collected randomly and monthly from the Gulf of Obhor, Red Sea, Jeddah coast, Saudi Arabia during the period from February 2018 to January 2019. The Global Positioning System (GPS) reading of N 21.745469, E 39.130233 (Fig. 1). Snails were collected by hand. They were deposit in glass containers contain fresh seawater and were moved to the Parasitology Laboratory, Department of Biology, Faculty of Science (Fig. 2). They were exposed to artificial light for two hours for emerging cercariae. The shedding cercariae were stained using the vital methylene blue stain and were identified (Hassan et al., 2018b; Al-Solami et al., 2019).

Collection of Digestive Gland-Gonad (DGG), hemolymph, and SCW

\section{Digestive Gland-Gonad (DGG) collection}

Shells were removed and each digestive gland-gonad (DGG) of marine snails have been dissected and separated carefully from the remaining viscera. Then stored at $-20^{\circ} \mathrm{C}$ until analysis (Hunsberger et al., 2013; Hunsberger et al., 2014).

\section{Hemolymph collection}

Hemolymph has been collected by cracking the shell within a Petri dish, pushing the foot, and obtaining the hemolymph through cardiac punction and from the edge using a pipette and stored in microtubes which are maintained at $-20^{\circ} \mathrm{C}$ until their utilizations for the biochemical analysis. The samples have been maintained in an ice bath during the dissection (Bandstra et al., 2006; Lustrino et al., 2010).

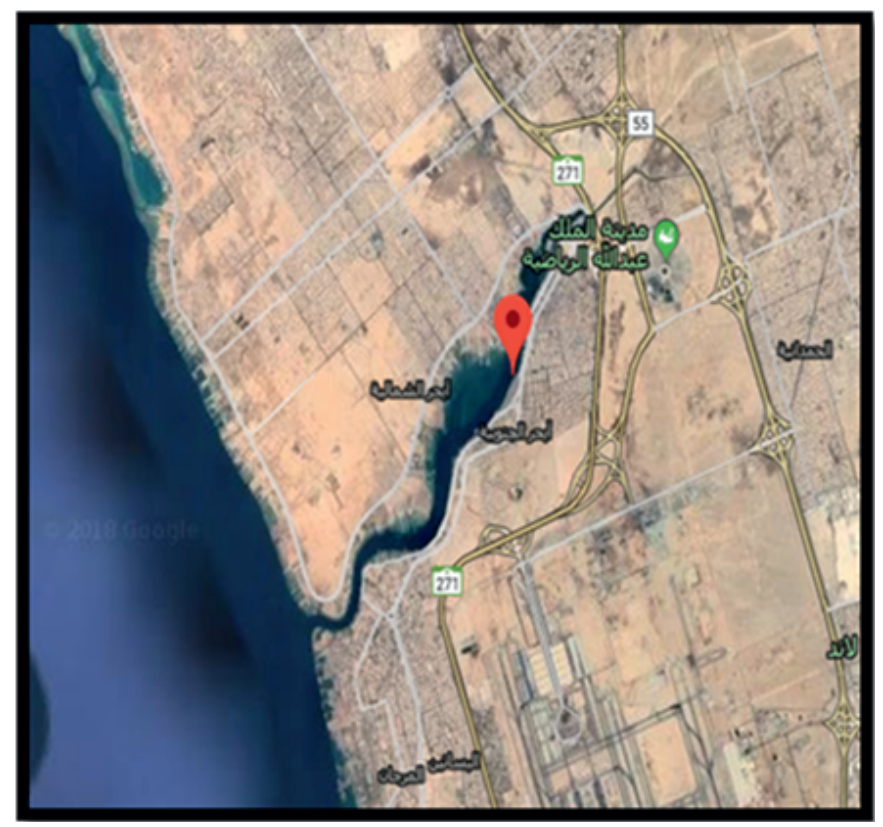

Fig. 1. Snail's collection site at Obhor, Jeddah coast, Red Sea (by Google map). 


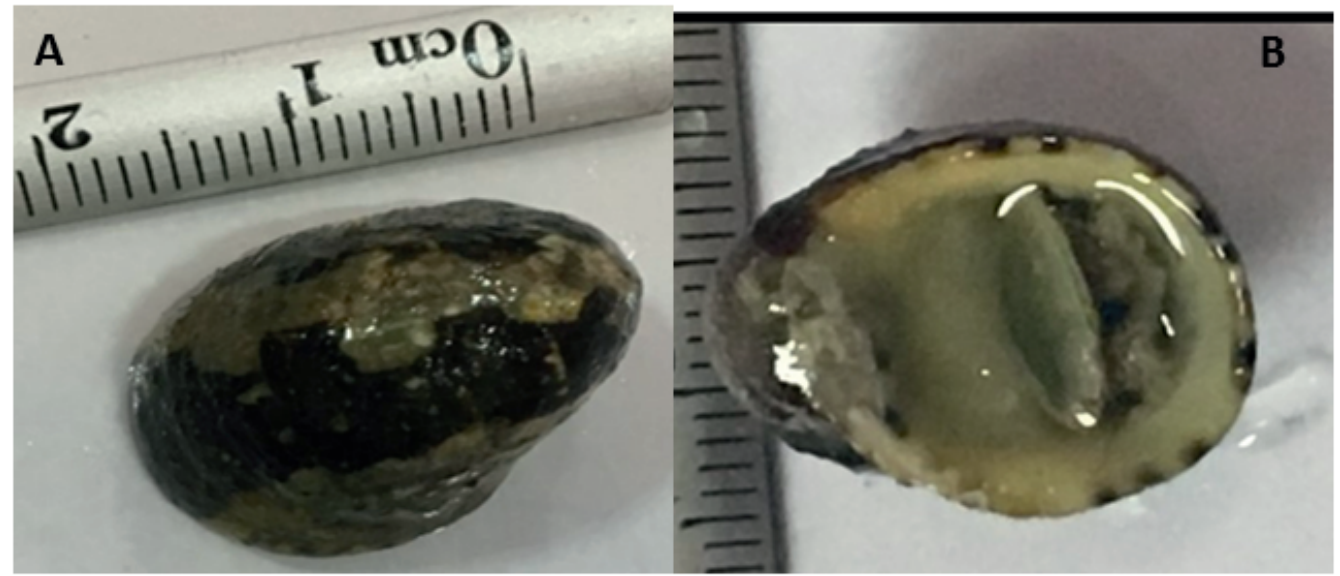

Fig. 2. The collected snail species, Nerita polita, A: Dorsal view, B: ventral view

\section{Snail Conditioned Water (SCW) collection}

Snails (10mm diameter) were put in a glass beaker containing $1 \mathrm{ml}$ distilled water at room temperature for two hours then filtered through a glass wool column to remove fecal debris. The filtrate has been collected in glass vial and used the same day of collection (Fried \& Reddy, 1999).

Analysis of triglycerides, cholesterol, and phospholipids in DGG, hemolymph, and SCW of Nerita polita

Determination of triglycerides content of the snails was done according to the methods of Inouye and Lotufo (2006) and Park et al. (2016). Whereas, determination of cholesterol contents of the snails was done using the methods of Momose et al. (1963). The determination of phospholipid contents of the snails was done by the methods of Bagniski and Zak (1960).

Minerals analysis in DGG and shells of the Nerita polita

Digestive Gland Gonad complex (DGG) and shell samples were analyzed by a modified procedure from the Association of Official Analytical Chemists (AOAC). According to the methods of Thomson and Robinson (1980) and Helvich (1990).

\section{Statistical analysis}

All statistical analysis was performed using the SPSS software program (version 25). Microsoft Office Excel 2010 was used for drawing graphing (Hassan et al., 2018b).

\section{Ethical Approval and/or Informed Consent}

Informed consent was obtained from all individuals included in this study. The conducted research is not related to human or animal use

\section{Results}

A total of 875 snails of $N$. polita were collected, of which $4.30 \%$ were found infected with ocellate furcocercus cercaria, Trichobilharzia regenti (Fig. 3) and $16.12 \%$ with xiphidiocercaria cercaria, Litorina saxatilis VII (Fig. 4). As shown in Figure 5, according to the length of snail, the total infection highest $(40 \%)$ in $21-22.9$ $\mathrm{mm}$ long snails and lowest (10\%) in $11-12.9 \mathrm{~mm}$ snails. The infection percentage in the $9-10.9 \mathrm{~mm}$ length was $14.28 \% \mathrm{com}$ pared to that in the length of $15-16.9 \mathrm{~mm}(16 \%)$. In the lengths

Table 1. Concentrations of triglycerides, cholesterol, and phospholipids in DGG $(\mathrm{mg} / \mathrm{g})$ of Nerita polita in infected versus uninfected snails.

T- test performed at $95 \%$ confidence level $(p \leq 0.05)$.

\begin{tabular}{lccccc}
\hline & $\begin{array}{c}\text { Uninfected } \\
(\mathrm{mg} / \mathrm{g})\end{array}$ & $\begin{array}{c}\text { Infected with ocellate } \\
\text { furcocercus cercaria } \\
(\mathrm{mg} / \mathrm{g})\end{array}$ & $\begin{array}{c}P \\
\text { value }\end{array}$ & $\begin{array}{c}\text { Infected with } \\
\text { xiphidiocercaria } \\
(\mathrm{mg} / \mathrm{g})\end{array}$ & $\begin{array}{c}P \\
\text { value }\end{array}$ \\
\hline Triglycerides & $0.53 \pm 0.021$ & $0.3743 \pm .059$ & $0.007^{*}$ & $0.597 \pm 0.058$ & $0.021^{*}$ \\
Cholesterol & $1.63 \pm 0.126$ & $1.380 \pm 0.202$ & $0.02^{*}$ & $1.786 \pm 0.178$ & $0.03^{*}$ \\
Phospholipids & $0.173 \pm 0.054$ & $0.664 \pm 0.157$ & 0.06 & $0.919 \pm 0.165$ & $0.010^{*}$ \\
\hline
\end{tabular}

*Significant $\mathrm{P} \leq 0.05$. 


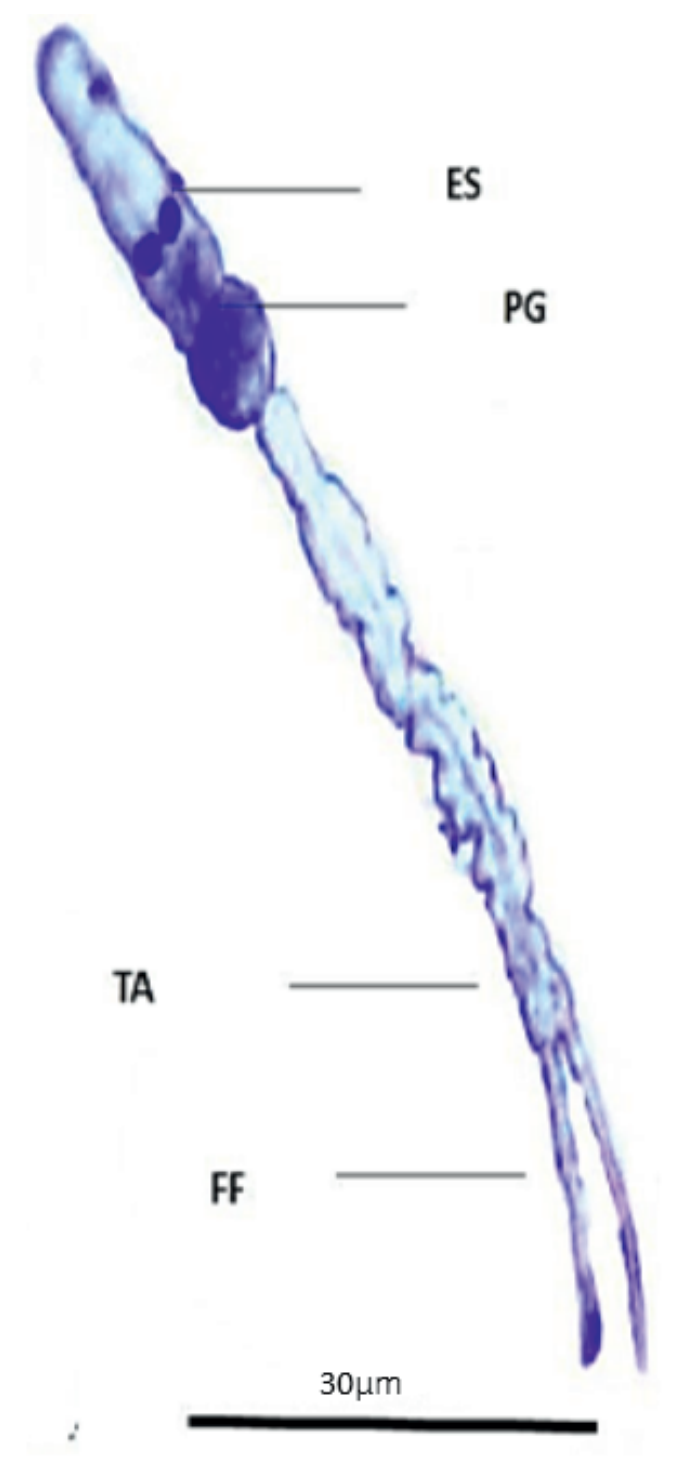

Fig. 3. Photomicrograph of the ocellate furcocercus cercaria, Trichobilharzia regenti (Faust,1918) collected from the snail, Nerita polita; eyespots (ES), penetration glands (PG) and fork tail (FT) (methylene blue-stained). of $17-18.9 \mathrm{~mm}$ and $19-20.9 \mathrm{~mm}$, infection prevalence was $33.34 \%$ and $29.42 \%$ respectively.

The biochemical analysis of triglycerides, cholesterol, and phospholipids in the DGG complex of snails infected with ocellate furcocercus cercaria showed a significant decline in triglycerides $(P=$ $007)$ and cholesterol $(P=0.02)$ while phospholipids were insignificantly increased $(P=0.06)$. In the case of xiphidiocercaria infection, DGG complex showed a significant increase in triglycerides $(P=0.021)$, cholesterol $(P=0.03)$ and phospholipids $(P=0.01)$ compared to uninfected snails (Table 1)

The effect of infection with ocellate furcocercus cercaria and xiphidiocercaria on the hemolymph of Nerita polita showed a significant decrease in triglycerides $(P=0.005$ and 0.002 , respectively) and cholesterol $(P=0.003$ and 0.01 , respectively) in hemolymph and an insignificant increase in phospholipids of hemolymph ( $P=0.075$ and 0.175 , respectively) in infected snails compared with non-infected one as shown in (Table 2).

Table 3 shows that the triglycerides $(P=0.012)$ and cholesterol $(P=0.004)$ in SCW of Nerita polita, were significantly lower in infection with ocellate furcocercus cercaria than uninfected snails. Whereas, Triglycerides $(P=0.1)$ and cholesterol $(P=0.375)$ are insignificantly decreased in xiphidiocercaria infected snails compared with non-infected ones. The phospholipids were insignificantly increased $(P=0.231)$ in infection with furcocercus infection and significantly $(P=0.031)$ in xiphidiocercaria infected snails than uninfected.

\section{Changes in minerals resulting from snail's infection}

The DGG complex and shell of Nerita polita, infected with ocellate furcocercus cercaria and xiphidiocercaria as well as uninfected snails were analyzed to determine minerals such as calcium $(\mathrm{Ca})$, zinc $(\mathrm{Zn})$, lead $(\mathrm{Pb})$, sodium $(\mathrm{Na})$, manganese $(\mathrm{Mn})$, magnesium $(\mathrm{Mg})$, potassium $(\mathrm{K})$, iron $(\mathrm{Fe})$, copper $(\mathrm{Cu})$ and cadmium $(\mathrm{Cd})$. Biochemical data in the DDG complex of both infected and non-infected snails were compared. Only $\mathrm{Cu}(P=0.049)$ showed a significant increase and $\mathrm{K}$ was significantly decreasing $(P=0.005)$ in furcocercous infected $N$. polita snails and only Na was significantly increased $(P=0.019)$ in xiphidiocercaria, infected snails. All other parameters were insignificantly associated (Table 4).

Table 2. Concentrations of triglycerides, cholesterol, and phospholipids in hemolymph $(\mathrm{mg} / \mathrm{g})$ of Nerita polita in infected versus uninfected snails. T-test performed at $95 \%$ confidence level ( $p \leq 0.05)$.

\begin{tabular}{lccccc}
\hline & $\begin{array}{c}\text { Uninfected } \\
(\mathbf{m g} / \mathbf{g})\end{array}$ & $\begin{array}{c}\text { Infected with ocellate } \\
\text { furcocercus cercaria } \\
(\mathbf{m g} / \mathbf{g})\end{array}$ & $\begin{array}{c}\mathbf{P} \\
\text { value }\end{array}$ & $\begin{array}{c}\text { Infected with } \\
\text { xiphidiocercaria } \\
(\mathbf{m g} / \mathbf{g})\end{array}$ & $\begin{array}{c}\mathbf{P} \\
\text { value }\end{array}$ \\
\hline Triglycerides & $0.380 \pm 0.098$ & $0.110 \pm 0.054$ & $0.005^{*}$ & $0.141 \pm 0.065$ & $0.002^{*}$ \\
Cholesterol & $1.339 \pm 0.329$ & $0.110 \pm 0.105$ & $0.003^{*}$ & $0.684 \pm 0.0256$ & $0.010^{*}$ \\
phospholipids & $0.077 \pm 0.0077$ & $0.523 \pm 0.040$ & 0.075 & $0.253 \pm 0.0163$ & 0.175 \\
\hline${ }^{*}$ Significant $P \leq 0.05$ & & & & &
\end{tabular}

\footnotetext{
${ }^{*}$ Significant $\mathrm{P} \leq 0.05$.
} 


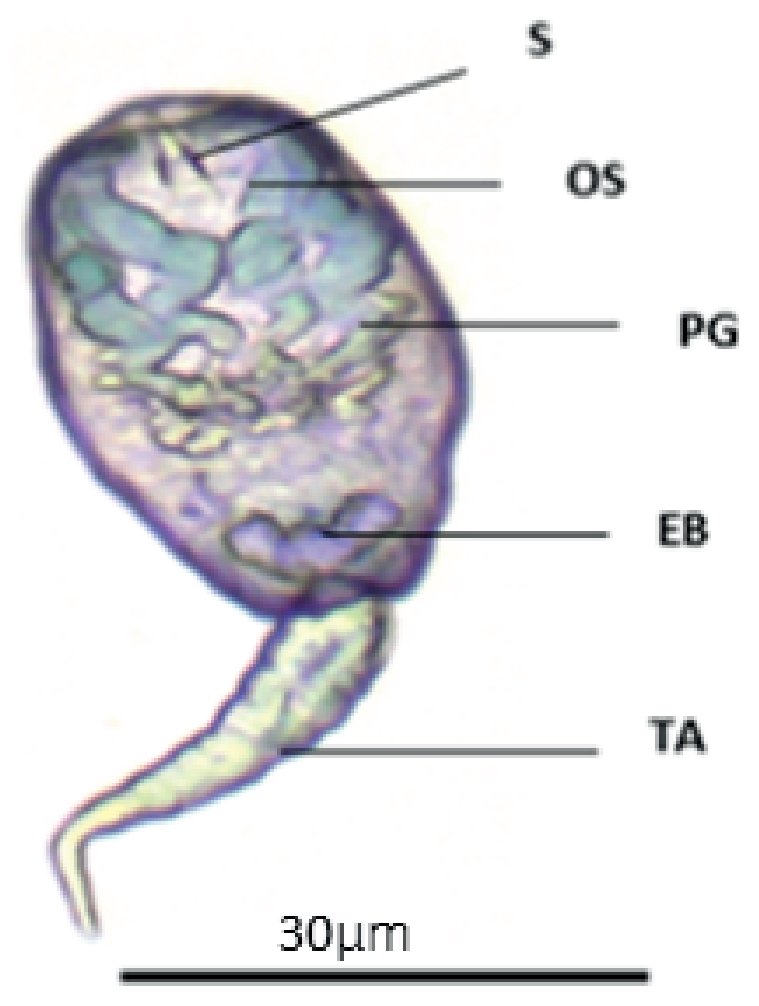

Fig. 4. Photomicrograph of the xiphidiocercaria, Litorina saxatilis VII collected from the snail, Nerita polita; oral sucker (OS), stylet (S), penetration glands (PG), excretory bladder (EB) and small tail (TA) (methylene blue- stained).

The shell of Nerita polita infection with ocellate furcocercus showed a significant increase $(P=0.040)$ in $\mathrm{Na}$ content and, insignificant decrease in $\mathrm{Zn}(P=0.935)$ than non-infected snails. All other parameters were insignificantly associated.

In shells of xiphidiocercaria infected snails $\mathrm{Ca}(P=0.005)$, $\mathrm{Na}$ $(P=0.031), \operatorname{Mg}(P=0.045)$ showed significantly increased levels; and only Fe showed a significantly decreased level $(P=0.048)$. All other parameters were insignificantly associated (Table 5).

\section{Discussion}

The present work discussed the influence of infection by trematode larvae on the profile of triglyceride, cholesterol, phospholipids, and some minerals in Nerita polita snails over one year. The infection by ocellate furcocercus cercaria and xiphidiocercaria resulted in a significant reduction in triglyceride levels $(P=0.005$ and $P=0.002)$ respectively) in the hemolymph of Nerita polita. These results are following Pinheiro et al. (2004); Pinheiro et al. (2005); Pinheiro et al. (2009); Tunholi-Alves et al. (2011) who suggested the use of triglycerides as a source of energy by the developing larvae during their asexual multiplication when the miracidium develops into a sporocyst, that develops many cercariae. The development of trematode larval stages inside the snail hosts consume a great amount of lipids to build their new organs and membranes.

Invasion of snail intermediate hosts by trematodes activates several metabolic interactions, needed for the development and multiplication of the parasite. This may consume the energy reserves of the host, primarily polysaccharides causing the snails to utilize other substances like proteins and lipids to maintain the essential needs for the parasite development (Becker, 1980; Pinheiro et al., 2009; Tunholi et al., 2011; Tunholi-Alves et al., 2012; Tunholi-Alves et al., 2013; Alves et al., 2014).

Tunholil-Alves et al. (2011) presented similar results in their study on the infection of Biomphalaria glabrata by Echinostoma paraensei. They found a decrease in the concentration of the triglycerides in the hemolymph of $B$. glabrata as an outcome of the process of the asexual reproduction of the parasite indicating that triglycerides are important for the parasite's development. They indicated that there are enzymes in trematodes responsible for lipid metabolism, particularly non-specific lipases and esterase confirming the usefulness of triglycerides as an energy source for the parasite. Infection by ocellate furcocercus cercaria and xiphidiocercaria both resulted in a significant decrease in triglyceride and cholesterol levels in the DGG complex of the infected N. polita. However, in the SCW the significant decrease was noted only in the triglyceride's levels in infection by ocellate furcocercus cercaria. Variations occurring in the late stage of the parasite's multiplication indicated that this stage has the maximum competition for nutrients with the host. Consequently, triglycerides are primarily hydrolyzed into free fatty acids and then oxidized in the mitochondrial matrix producing the energy required to meet the metabolic needs and minimizing the harmful effects of the infection (Tripathi \& Singh, 2002; Humiczewska \& Rajski, 2005).

Bandstra, et al. (2006); Fried, et al. (1989) observed a significant

Table 3. Concentrations of triglycerides, cholesterol, and phospholipids in SCW (mg/g) of Nerita polita in infected versus uninfected snails.

T-test performed at $95 \%$ confidence level $(p \leq 0.05)$.

\begin{tabular}{lccccc}
\hline & $\begin{array}{c}\text { Uninfected } \\
(\mathbf{m g} / \mathbf{g})\end{array}$ & $\begin{array}{c}\text { Infected with ocellate } \\
\text { furcocercus cercaria } \\
(\mathbf{m g} / \mathbf{g})\end{array}$ & $\begin{array}{c}\mathbf{P} \\
\text { value }\end{array}$ & $\begin{array}{c}\text { Infected with } \\
\text { xiphidiocercaria } \\
(\mathrm{mg} / \mathbf{g})\end{array}$ & $\begin{array}{c}\mathbf{P} \\
\text { value }\end{array}$ \\
\hline Triglycerides & $1.8 \pm 0.13$ & $0.691 \pm 0.069$ & $0.012^{*}$ & $0.0232 \pm 0.0012$ & 0.10 \\
cholesterol & $1.765 \pm 0.635$ & $0.427 \pm 0.196$ & $0.004^{*}$ & $0.573 \pm 0.362$ & 0.375 \\
phospholipids & $0.045 \pm 0.0034$ & $0.146 \pm 0.053$ & 0.231 & $0.196 \pm 0.023$ & $0.031^{*}$ \\
\hline${ }^{*}$ Significant $\mathrm{P} \leq 0.05$ & & & & &
\end{tabular}

*Significant $P \leq 0.05$ 
Table 4. Minerals concentration in DGG of Nerita polita in infected versus uninfected.

T-test performed at $95 \%$ confidence level $(p<0.05)$.

\begin{tabular}{lccccc}
\hline Metal & $\begin{array}{c}\text { Uninfected } \\
(\mathbf{m g} / \mathbf{g})\end{array}$ & $\begin{array}{c}\text { Infected with ocellate } \\
\text { furcocercus }(\mathbf{m g} / \mathbf{g})\end{array}$ & $\begin{array}{c}\mathbf{P} \\
\text { value }\end{array}$ & $\begin{array}{c}\text { Infected with } \\
\text { xiphidiocercaria } \\
(\mathbf{m g} / \mathbf{g})\end{array}$ & $\begin{array}{c}\mathbf{P} \\
\text { value }\end{array}$ \\
\hline Calcium $(\mathrm{Ca})$ & $4.935 \pm 7.261$ & $5.002 \pm 9.653$ & 0.19 & $4.943 \pm 7.963$ & 0.179 \\
Zinc $(\mathrm{Zn})$ & $0.160 \pm 0.212$ & $0.499 \pm 0.125$ & 0.12 & $0.958 \pm 0.286$ & 0.256 \\
Lead $(\mathrm{Pb})$ & $0.009 \pm 0.025$ & $0.031 \pm 0.896$ & 0.09 & $0.033 \pm 0.652$ & 0.236 \\
Sodium $(\mathrm{Na})$ & $24.590 \pm 7.023$ & $25.400 \pm 8.694$ & 0.103 & $28.330 \pm 7.653$ & $0.019^{*}$ \\
Manganese $(\mathrm{Mn})$ & $0.012 \pm 0.021$ & $0.096 \pm 0.895$ & 0.258 & $0.218 \pm 0.986$ & 0.325 \\
Magnesium $(\mathrm{Mg})$ & $2.858 \pm 4.524$ & $2.511 \pm 0.965$ & 0.635 & $3.112 \pm 7.653$ & 0.145 \\
Potassium (K) & $3.380 \pm 8.305$ & $2.807 \pm 0.852$ & $0.005^{*}$ & $3.616 \pm 8.643$ & 0.796 \\
Iron (Fe) & $0.243 \pm 0.125$ & $0.351 \pm 0.986$ & 0.075 & $0.519 \pm 0.256$ & 0.142 \\
Copper $(\mathrm{Cu})$ & $0.051 \pm 0.611$ & $2.032 \pm 0.896$ & $0.049^{*}$ & $0.833 \pm 0.563$ & 0.325 \\
Cadmium $(\mathrm{Cd})$ & $0.014 \pm 0.210$ & $0.008 \pm 0.587$ & 0.598 & $0.021 \pm 0.985$ & 0.186 \\
\hline${ }^{*}$ Significant $\mathrm{P} \leq 0.05$ & & & & &
\end{tabular}

reduction in the triglyceride fraction in the DGG complex of $\mathrm{Bi}$ omphalaria glabrata infected by Echinostoma caproni. Cline et al. (2000) deduced significantly lower levels of triacylglycerol in the DGG complex of Cerithidia californica snails infected with three species of tritrud larvae: Euhaplorchis californiensis, Cloacitrema michiganensis, and Mesostephanus appendiculatus.
In our study alterations in the amount of cholesterol in the DGG complex and hemolymph were observed in the Nerita polita snails infected by ocellate furcocercus and xiphidiocercaria. Marsit et al. (2000) suggested that this lipid is included in the constituents of the parasite larval stages, during developmental mitotic activity related to miracidium conversion to sporocyst and its following de-

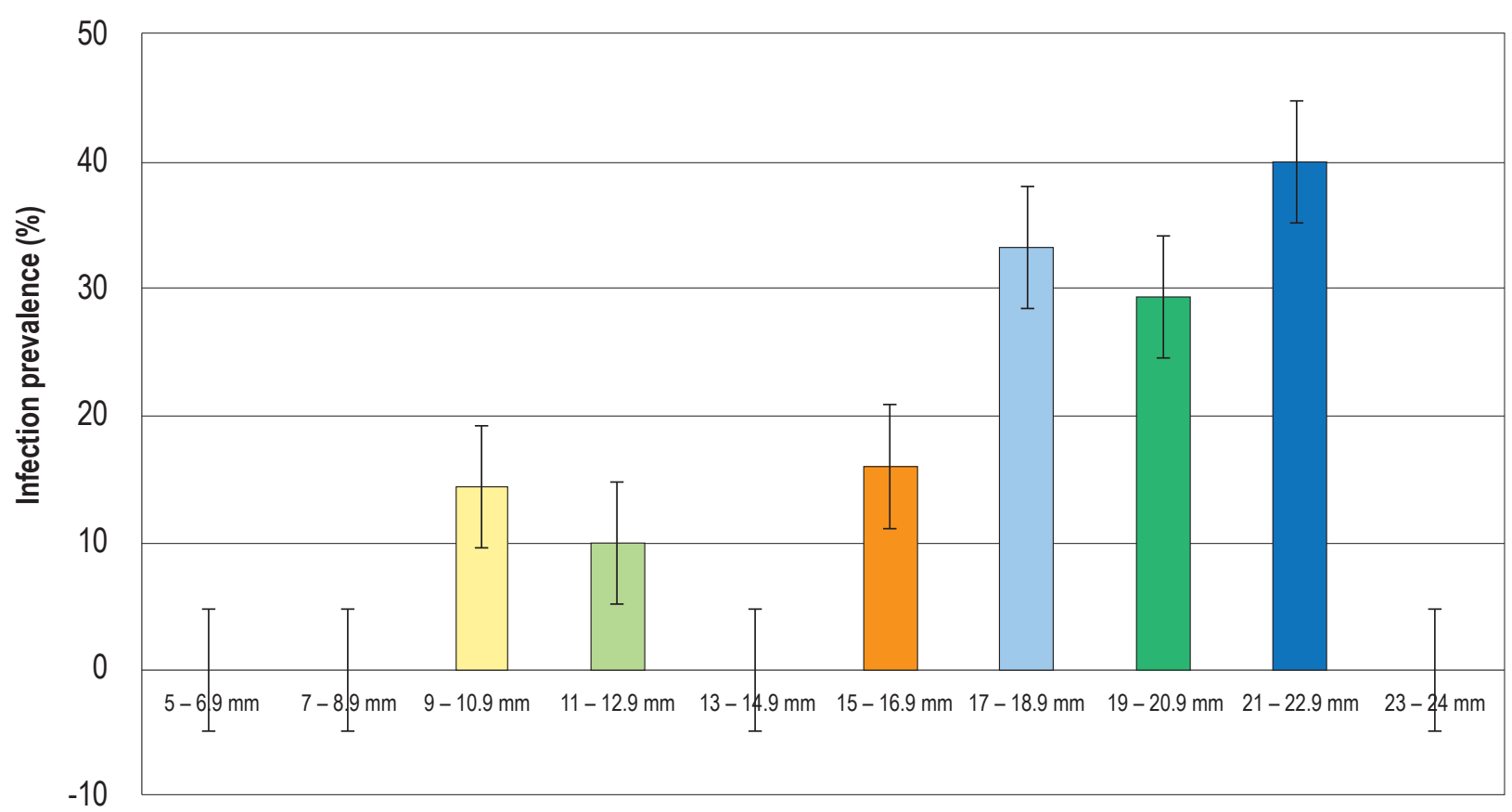

Snail length class $(\mathrm{mm})$

Fig. 5. The infection prevalence of Nerita polita in relation to snail length. 
Table 5. Minerals concentration in Nerita polita shell in infected versus uninfected snails.

T-test performed at $95 \%$ confidence level $(p<0.05)$.

\begin{tabular}{lccccc}
\hline Metal & $\begin{array}{c}\text { Uninfected } \\
(\mathbf{m g} / \mathbf{g})\end{array}$ & $\begin{array}{c}\text { Infected with ocellate } \\
\text { furcocercus }(\mathbf{m g} / \mathbf{g})\end{array}$ & $\begin{array}{c}\mathbf{P} \\
\text { value }\end{array}$ & $\begin{array}{c}\text { Infected with } \\
\text { xiphidiocercaria } \\
(\mathbf{m g} / \mathbf{g})\end{array}$ & $\begin{array}{c}\mathbf{P} \\
\text { value }\end{array}$ \\
\hline $\mathrm{Ca}$ & $0.478 \pm 0.563$ & $0.645 \pm 0.796$ & 0.070 & $4.927 \pm 0.896$ & $0.005^{*}$ \\
$\mathrm{Zn}$ & $0.657 \pm 0.456$ & $0.577 \pm 0.498$ & 0.935 & $0.884 \pm 0.635$ & 0.653 \\
$\mathrm{~Pb}$ & $0.060 \pm 0.463$ & $0.062 \pm 0.463$ & 0.369 & $0.061 \pm 0.493$ & 0.492 \\
$\mathrm{Na}$ & $20.750 \pm 7.652$ & $25.50 \pm 6.52$ & $0.040^{*}$ & $25.300 \pm 5.63$ & $0.031^{*}$ \\
$\mathrm{Mn}$ & $0.152 \pm 0.468$ & $0.225 \pm 0.68$ & 0.635 & $0.213 \pm 0.860$ & 0.365 \\
$\mathrm{Mg}$ & $2.101 \pm 1.568$ & $2.320 \pm 0.652$ & 0.452 & $2.596 \pm 0.498$ & $0.045^{*}$ \\
$\mathrm{~K}$ & $0.303 \pm 0.356$ & $0.983 \pm 0.395$ & 0.398 & $1.194 \pm 0.963$ & 0.254 \\
$\mathrm{Fe}$ & $0.036 \pm 0.492$ & $0.065 \pm 0.783$ & 0.148 & $0.010 \pm 0.796$ & $0.053^{*}$ \\
$\mathrm{Cu}$ & $0.026 \pm 0.468$ & $0.124 \pm 0.361$ & 0.398 & $0.011 \pm 0.698$ & 0.235 \\
$\mathrm{Cd}$ & $0.021 \pm 0.148$ & $0.102 \pm 0.952$ & 0.985 & $0.001 \pm 0.496$ & 0.076 \\
\hline${ }^{*}$ Significant $\mathrm{P} \leq 0.05$ & & & & &
\end{tabular}

velopment leading to fast cell and tissue construction in the larvae. Free sterol, primarily cholesterol has been reported as the major constituent of the trematode larval stages. The resulting rise in cholesterol may be due to two mechanisms: first is the increase in biosynthesis of cholesterol, and second is the remodeling of cell membranes. The latter is accompanied by the liberation of its cholesterol molecules which causes membrane fluidity and raises the rate of metabolic processes including membrane proteins like those working in the transport chain of electrons in the mitochondria and altering the cell permeability (Narayanan \& Venkateswarara, 1980). It appears that cholesterol levels are maintained at a very tight range and when alteration occurs, there is need to return rapidly to the homeostatic level (Lustrino et al., 2010).

In the present study, there was a significant reduction in cholesterol levels, in the DGG complex of N. polita snails infected with ocellate furcocercus cercaria as compared to higher cholesterol levels associated with xiphidiocercaria infection. The infection by ocellate furcocercus cercaria and xiphidiocercaria also resulted in a significant decrease in triglyceride levels, in the DGG complex of the infected snails. In the SCW of snails infected by ocellate furcocercus cercaria and xiphidiocercaria there was a significant decrease in the triglycerides. Variations in levels associated with the late stage of parasites' multiplication indicated that this stage has the maximum competition for nutrients with the host. Consequently, triglycerides are primarily hydrolyzed into free fatty acids and then oxidized in the mitochondrial matrix producing the energy required to meet the metabolic needs and minimizing the harmful effects of the infection (Tripathi \& Singh, 2002; Humiczewska \& Rajski, 2005). Bandstra et al. (2006); Fried et al. (1989) observed a significant reduction in the triglyceride fraction in the DGG complex of $\mathrm{Bi}$ - omphalaria glabrata infected by Echinostoma caproni. Cline et al. (2000) using high-performance layer chromatography (HPTLC) analysis showed that triacylglycerol in the DGG of snails Cerithidia californica infected with three species of tritrud larvae; Euhaplorchis californiensis, Cloacitrema michiganensis, and Mesostephanus appendiculatus was significantly less than that of the controls of N.polita snails. This shortage may be due to the consumption of triglycerides by both parasite and host to maintain the energy for metabolism. The increase in cholesterol content is due to the great change in cellular structures of the host especially in the DGG as a result of the severe damage the parasites done. Furthermore, the alteration in lipids profile due to infection indicate the importance of lipid molecules in the snail hosts. Alves et al. (2014) supposed that triglycerides are considered as the first energy resources for the snail and parasite, while cholesterol is included in a manufacturing cell and tissue structures of both organisms.

In our work the results showed an insignificant increase in the phospholipids in the hemolymph of $N$. polita infected by both ocellate furcocercus and xiphidiocercaria. Phospholipids recorded increase in the SCW was significant only in association with infection by xiphidiocercaria of N.polita. This led Bui et al. (2016) to hypothesize that the level of phosphatidylethanolamine (PE) in B. glabrata is not affected by $S$. mansoni infection, but by the physiological change of the snail's body as it ages. To explain the difference in trends of phosphatidylserine serine (PS) level, they propose two explanations: 1) the changes in phosphatidylserine serine (PS) level caused by the parasite outweigh the changes that would otherwise occur naturally as the snail ages, thus skewing the overall trends of phosphatidylserine (PS) level; 2) the parasitism affected the metabolism of the snail, thus causing a difference in the way 
the snail physiology changes as it ages. They found several differences in phospholipid profile of $B$. glabrata DGG complex induced by the parasitism.

In a report by Cline et al. (2000) parasitism by three larval trematodes, Euhaplorchis californiensis, Cloacitrema michiganensis, and Mesostephanus appendiculatus resulted in a significant increase in phospholipid and phosphatidylethanolamine content in the DGG complex compared with control levels; whereas infection by both $M$. appendiculatus and $E$. californiensis caused a significant increase in phosphatidylcholine content. This clarifies that larval parasitism in the same snail species will induce different lipid profiles in the host, and this can provide chemotaxonomic information to differentiate between larval trematodes from the same snail host

According to Thompson and Mejia-Scale (1993), the role of lipids as a storage reserve in gastropods is not clear, and the role of lipids in metabolisms of snails and the significance of lipids to developing larvae require further investigation. Schistosoma parasites appear to distort the neutral lipids composition of the snail host, especially during infection. Other studies by Thompson (1987); Fried et al. (1995); Eberemu (2018) also showed that in the presence of parasites there is an initial increase of neutral fat in the infected host cells which is rapidly degraded to fatty acids, as the infection progresses.

The effect of larval trematodes infection on quantities of minerals was studied using different devices. Ong et. al. (2004) using inductively coupled plasma atomic emission spectrometry reported an insignificant decline in the concentrations of $\mathrm{Cu}, \mathrm{Fe}$, and $\mathrm{K}$ and a significant decrease in the concentration of $\mathrm{Zn}$ and $\mathrm{Pb}$ in infected snails. Using flame atomic absorption spectrometry, Mostafa (2008) investigated the amount of some metallic ions in the DGG complex and shells of the model Lymnaea stagnalis infected by Fasciola gigantica. He recorded a significant increase in the concentrations of $\mathrm{Zn}, \mathrm{K}$, and $\mathrm{Cu}$, an insignificant increase in $\mathrm{Fe}$, and a significant decrease in $\mathrm{Pb}$ and $\mathrm{Na}$ in infected compared to noninfected snails. Infected pulmonate snails were found to sustain more $\mathrm{CaCo} 3$ in their shells than non-infected ones (Ong et al., 2004). Silva et al. (2017) recorded insignificant alteration in the amount of $\mathrm{Ca}$ and glucose in the hemolymph of infected and non-infected snails analyzed by an ion-exchange column and high-performance liquid chromatography.

The reasons for metallic ions fluctuation as a result of trematode infections were due to larval stages (rediae, sporocysts, and free cercariae) affection of the ionic balance through influx and outflux of ions from larvae to the snail host. Destruction of the digestive gland cells by larval trematodes probably reduced the storage volume and capacity of elements in the infected snails. The parasites could affect calcium distribution leading to its deposition in the shell and mantle. The hypothesis of hyper-calcification of snail shells induced by trematode larvae should be verified under natural conditions (Evans et al., 2001; Kaufer et al., 2002; Zbikowska, 2003; Ong et al., 2004; Hassan 2008).

\section{Conclusions}

Our results of biochemical changes showed a fluctuation in the concentration of lipids and minerals between increase and decrease in snail's DGG complex, hemolymph, and SCW. The reduction of triglycerides and cholesterol in the SCW may affect the therapeutic value of the studied snails. The nutritive value of the snails is affected by infection through the decrease in some lipids and minerals. Further qualitative studies are recommended.

\section{Conflict of interest}

\section{Authors state no conflict of interest}

\section{Acknowledgment}

I would like to thank King Abdul Aziz University, the great scientific edifice, the Faculty of Sciences, biological Sciences Department for providing the opportunity to study and to allocate laboratories and private spaces to us.

\section{References}

Ab Lah, R., Smith, J., Savins, D., Dowell, A. Busher, D., BenkenDROFF, K. (2017): Investigation of nutritional properties of three species of marine turban snails for human consumption. Food Sci Nutr, 5(1): 14 - 30. DOI: 10.1002/fsn3.360

AdIKWU, M.U., ALOZIE, B.U. (2007): Application of snail mucin dispersed in detarium gum gel in wound healing. SRE, 2: $195-198$. DOI: $10.5897 /$ SRE. 9000205

ADIKWU, M.U., ENEBEKE, T.C. (2007): Evaluation of snail mucin dispersed in Brachystegia gum gel as a wound-healing agent. Anim. Res. Int, 4(2): 685 - 697. DOI: 10.4314/ari.v4i2.40818

Al-Solami, M., Hassan, S., Hassan, A. (2019): Molecular Method vs Traditional methods for Estimating the Prevalence of Larval Trematode Infections in Some Red Sea Snails. Int. J. Pharm. Res. Allied Sci., 8 (2): 1 - 13

Alves, H., Tunholi-Alves, V.M., Tunholi, V.M., Gôlo, P., BitTenCOURT, V.R.E.P., PINHEIRO, J. (2014): Changes in the lipid profile of Bradybaena similaris (Férussac, 1821) (Gastropoda, Xanthonychidae) during the development of Eurytrema coelomaticum (Giard and Billet, 1892) (Digenea, Dicrocoeliidae). Exp Parasitol, 144: 52 - 56. DOI: 10.1016/j.exppara.2014.06.010

BAGNISKI, E., ZAK, B. (1960): Micro-determination of serum phosphate and phospholipids. Clin Chim Acta, 5(6): 834 - 838. DOI: 10.1016/0009-8981(60)90117-0

Bandstra, S.R., Fried, B., Sherma, J. (2006): High-performance thin-layer chromatographic analysis of neutral lipids and phospholipids in Biomphalaria glabrata patently infected with Echinostoma caproni. Parasitol Res, 99(4): 414 - 418. DOI: 10.1007/s00436007-0798-y

BECKER, W. (1980): Metabolic interrelationship of parasitic trem- 
atodes and molluscs, especially Schistosoma mansoni in Biomphalaria glabrata. Parasitol Res, 63(2): 101 - 111. DOI: 10.1007I bf00927526

BuI, Q. H.D., Fried, B., Sherma, J. (2016): High-performance thin-layer chromatographic analysis of phospholipids in Biomphalaria glabrata snails infected with Schistosoma mansoni. Trends Chromatogr,10: 7 - 12. DOI: 10.1007/s00436-006-0180-5

Cline, D.J., Fried, B., SHermA, S. (2000): High-performance thin-layer chromatographic analysis of neutral lipids and phospholipids in Cerithidia californica (Gastropoda) infected with three species of larval trematodes. Acta Chromatogr, 10: 183 - 189

Eberemu, N. C. (2018): Impact of schistosoma haematobium infection and starvation on some neutral and polar lipids contect of Bulinus truncates. FJS, 2(3): $224-232$

Etim, L., Alerushi, C., Obande, G.A. (2016): Antibacterial Properties of Snail Mucus on Bacteria Isolated from Patients with Wound Infection. Br Microbiol Res J, 11(2): 1 - 9. DOI: 10.9734/ BMRJ/2016/21731

Evans, D.W., IRWIN, S.W.B., FitzpatRick, S. (2001): The effect of digenean (Platyhelminthes) infections on heavy metal concentrations in Littorina littorea. J Mar Biol Assoc UK, 81: 349 - 350. DOI: 10.1017/S0025315401003873

Fried, B., ReddY, A. (1999): Effects of snail-conditioned water from Biomphalaria glabrata on hatching of Echinostoma caproni miracidia. Parasitol Res, 85(2): 155 - 157. DOI: $10.1007 /$ s004360050526

Fried, B., Lewis JR, P.D., Beers, K. (1995): Thin-layer chromatographic and histochemical analyses of neutral lipids in the intramolluscan stages of Leucochloridium variae (Digenea, Leucochloridiidae) and the snail host, Succinea ovalis. J Parasitol, 81(1): 112 - 114. DOI: $10.2307 / 3284019$

Fried, B., Schafer, S., Kim, S. (1989): Effects of Echinostoma caproni infection on the lipid composition of Biomphalaria glabrata. Int $J$ Parasitol, 19(3): 353 - 354. DOI: 10.1016/0020-7519(89)90149-5 GIOKAS, S., Pafilis, P., Valakos, E. (2005): Ecological and physiological adaptations of the land snail Albinaria caerulea (Pulmonata: Clausiliidae). J Molluscan Stud, 71(1): 15 - 23. DOI: 10.1093/ mollus/eyi001

HASSAN, A. (2008): Effects of digenean larval infection on the shells and soft parts of their intermediate host Lanistes carinatus. J Egypt Soc Parasitol, 38 (3): 805 - 812

Hassan, A., Al-Solami, M., Hassan, S. (2018a): Identification of some trematode cercariae collected from six marine snail species belonging to the genus Nerita. J Egypt Soc Parasitol, 48(2): $251-258$

Hassan, A., Moharram, S., Al-Helal, H. (2018b): Role of parasitic helminthes in bioremediating some heavy metal accumulation in the tissues of Lethrinus mahsena. Turk J Fish Aquat Sci, 18: 435 - 443. DOI: 10.4194/1303-2712-v18_3_09

HeLviCH, K. (1990): Official methods of analysis (No. 630.24 A88 1990). Association of official analytical chemists (AOAC), 7: 39 - 65. Retrieved from https://law.resource.org/pub/us/cfr/ ibr/002/aoac.methods.1.1990.pdf

HUMICZEWSKA, M., RAJSKI, K. (2005): Lipids in the host-parasite system: digestive gland of Lymnaea truncatula infected with the developmental stages of Fasciola hepatica. Acta Parasitol, 50(3): $235-239$

Hunsberger, A., Degrandchamp, D., Fried, B., Sherma, J. (2014): Effects of high and low temperatures on the lipid content of the digestive gland-gonad complex of Biomphalaria glabrata as determined by high-performance thin layer chromatography. J Liq Chromatogr Relat Technol, 37(20): 2989 - 2999. DOI: 10.1080/10826076.2014.907106

Hunsberger, A., Fried, B., Sherma, J. (2013): Effects of Echinostoma caproni miracidia dose on the neutral and polar lipids of $\mathrm{Bi}$ omphalaria glabrata as determined by high-performance thin-layer chromatography. Acta Parasitol, 58(4): 615 - 618. DOI: 10.2478/ s11686-013-0180-4

INOUYE, L.S., LOTUFO, G.R. (2006): Comparison of macro-gravimetric and micro-colorimetric lipid determination methods. Talanta, 70(3): 584 - 587. DOI: 10.1016/j.talanta.2006.01.024

Kantawong, F., Thaweenan, P., Mungkala, S., Tamang, S., Manaphan, R., Wanachantararak, P., Chumnanpuen, P. (2016): Mucus of Achatina fulica stimulates mineralization and inflammatory response in dental pulp cells. Turk J Biol, 40(2): 353 - 359. DOl: 10.3906/biy1505-29

Kaufer, S.W., Chejlava, M., Fried, B., Sherma, J. (2002): Effects of Euhaplorchis califorensis (Trematoda) infection on metallic ions in the host snail Cerithidea californica. Parasitol Res, 88: 1080 - 1082. DOI: $10.1007 / s 00436-002-0718-0$

Lustrino, D., Tunholi-Alves, V.M., Tunholi, V. M., Marassi, M. P., PINHeIRo, J. (2010): Lipids analysis in hemolymph of African giant Achatina fulica (Bowdich, 1822) exposed to different photoperiods. Braz J Biol, 70(1): 129 - 134. DOI: 10.1590/s151969842010000100018

Marsit, C.J., Fried, B., Sherma, J. (2000): Neutral lipids in cercariae, encysted metacercariae, and rediae of Echinostoma caproni. $J$ Helminthol, 74(4): 365 - 367. DOI: 10.1017/S0022149X00000548 Momose, T., Ueda, Y., Yamamoto, K., Masumura, T., Ohta, K. (1963): Determination of Total Cholesterol in Blood Serum with Perchloric Acid-Phosphoric Acid-Ferric Chloride Reagent. Anal Chem, 35(11): 1751 - 1753. DOI: 10.1021/ac60204a062

MostafA, O.M.S. (2008): Effects of Fasciola gigantica experimental infection on some inorganic elements in the snail host. Lymnaea natalensis. Exp Parasitol, 118(4): 468 - 471. DOI: 10.1016/j.exppara.2007.10.009

Narayanan, R., Venkateswararao, P. (1980): Effect of xiphidiocercarial infection on oxidation of glycolytic and Krebs cycle intermediates in Lymnaea luteola (Mollusca). J Invertebr Pathol, 36(1): 21 - 24. DOI: 10.1016/0022-2011(80)90129-9

Ong, J. H. L., Chejlava, M., Fried, B., Koehnlein, K. M., Bosavage, G. L., SHERMA, J. (2004): Effects of Schistosoma mansoni infection on inorganic elements in the snail Biomphalaria glabrata. $J$ Helminthol, 78(4): 343 - 346. DOI: 10.1079/JOH2004244 
Park, J., Jeong, H.J., Yoon, E.Y., Moon, S.J., PARK, J., Jeong, H.J., Moon, S.J. (2016): Easy and rapid quantification of lipid contents of marine dinoflagellates using the sulpho-phospho-vanillin method. Algae, 31(4): 391 - 401. DOI: 10.4490/algae.2016.31.12.7

Pinheiro, J., JúnIoR, A.M., Lanfredi, R.M. (2009): Physiological changes in Lymnaea columella (Say, 1817) (Mollusca, Gastropoda) in response to Echinostoma paraensei Lie and Basch, 1967 (Trematoda: Echinostomatidae) infection. Parasitol Res, 106(1): 55 - 59. DOI: 10.1007/s00436-009-1630-7

Pinheiro, J., Junior, A.M., Attias, M., Lanfredi, R. M. (2004): Morphology of the rediae of Echinostoma paraensei (Trematoda: Echinostomatidae) from its intermediate host Lymnaea columella (Mollusca, Gastropoda). Parasitol Res, 93(3): 171 - 177. DOI: 10.1007/s00436-004-1110-z

Pinheiro, J., Maldonado, A., Attias, M., Lanfredi, R. M. (2005): Ultrastructure of the miracidium of Echinostoma paraensei Lie and Basch, 1967 (Trematoda, Echinostomatidae). Parasitol Res, 97(5): 367 - 372. DOI: 10.1007/s00436-005-1458-8

Silva, L.D., Amaral, V.C.S., Vinaud, M.C., Castro, A.M., Rezende, H.H. A., Santos, D.B., BezerRA, J.C.B. (2017): Changes in energetic metabolism of Biomphalaria glabrata (Mollusca, Planorbidae) in response to exogenous calcium. Braz. J. Biol., 77(2): $304-311$. DOI: 10.1590/1519-6984.13315

Smith, A.M., Robinson, T.M., Salt, M.D., Hamllton, K.S., Silvia, B.E., BLASIAK, R. (2009): Robust cross-links in molluscan adhesive gels: testing for contributions from hydrophobic and electrostatic interactions. Comp Biochem Physiol B Biochem Mol Biol, 152(2): 110 - 117. DOI: 10.1016/j.cbpb.2008.10.004

StOREY, K.B. (2002): Life in the slow lane: molecular mechanisms of estivation. Comp Biochem Physiol A Mol Integr Physiol, 133(3): 733 - 754. DOI: 10.1016/s1095-6433(02)00206-4

Stuart, J.A., Gillus, T.E., BallantYNe, J.S. (1998): Compositional correlates of metabolic depression in the mitochondrial membranes of estivating snails. Am J Physiol, 275(6): 1977 - 1982. DOI: 10.1152/ajpregu.1998.275.6.R1977

THomAs, S. (2013): Medicinal use of terrestrial molluscs (slugs and snails) with particular reference to their role in the treatment of wounds and other skin lesions. Retrieved from http://www.worldwidewounds.com/2013/July/Thomas/slug-steve-thomas.html Thompson, S. N., MeJIA-Scales, V. (1993): Effects of restricted food intake on hemolymph glucose concentration and digestive gland-gonad lipid level in the schistosome vector Biomphalaria glabrata (Say) (Gastropoda: Planorbidae). Veliger, 36(4); 425 - 427 THompson, S.N. (1987): Effect of Schistosoma mansoni on the gross lipid composition of its vector Biomphalaria glabrata. Comp Biochem Physiol B, 87(2): 357 - 360. DOI: 10.1016/03050491(87)90152-0
Thomson C.D., Robinson M.F. (1980): Selenium in human health and disease with emphasis on those aspects peculiar to New Zealand. Am J Clin Nutr, 33(2, 1): 303 - 323. DOI: 10.1093/ ajcn/33.2.303

Toledo, R., Munoz-Antoli, C., Esteban, J.G. (2014): Intestinal trematode infections. In: Toledo R., Fried B. (Eds) Digenetic Trematodes. Advances in Experimental Medicine and Biology, vol 766. Springer, New York, NY. DOI: 10.1007/978-1-4939-0915-5_7

TRIPATHI, P.K., SINGH, A. (2002): Toxic effects of dimethoate and carbaryl pesticides on carbohydrate metabolism of freshwater snail Lymnaea acuminata. Bull Environ Contam Toxicol, 68(4): 606 - 611. DOI: $10.1007 / \mathrm{s} 001280297$

Tunhol, V.M., Lustrino, D., Tunholi-Alves, V.M., Mello-Silva, C.C., Maldonado, A., Pinheiro, J., Rodrigues, M.D.L.D.A. (2011): Biochemical profile of Biomphalaria glabrata (Mollusca: Gastropoda) after infection by Echinostoma paraensei (Trematoda: Echinostomatidae). Parasitol Res, 109(3): 885 - 891. DOI: 10.1007/ s00436-011-2330-7

Tunholi-Alves, V.M., Tunholi, V.M., Garcia, J.S., Costa-Neto, S.F., Maldonado, A., Santos, M. A. J., Pinheiro, J. (2014): Changes in the calcium metabolism of Biomphalaria glabrata experimentally infected with Angiostrongylus cantonensis. J Helminthol, 88(2): 160 - 165. DOI: 10.1017/S0022149X12000867

Tunholi-Alves, V.M., Tunholi, V.M., Gôlo, P., Lima, M., GarCiA, J., JúNIOR, A.M., PINHEIRO, J. (2013): Effects of infection by larvae of Angiostrongylus cantonensis (Nematoda, Metastrongylidae) on the lipid metabolism of the experimental intermediate host Biomphalaria glabrata (Mollusca: Gastropoda). Parasitol Res, 112(5): 2111 - 2116. DOI: 10.1007/s00436-013-3308-4

Tunholi-Alves, V.M., Tunholi, V.M., Gôlo, P., Lustrino, D., Maldonado JR, A., Bittencourt, V. R. E. P., Pinheiro, J. (2011): Lipid levels in Biomphalaria glabrata infected with different doses of Echinostoma paraensei miracidia. Exp Parasitol, 128(3): 212 - 216. DOI: 10.1016/j.exppara.2011.03.009

Tunholi-Alves, V.M., Tunholi, V.M., Pinheiro, J., Thiengo, S.C. (2012): Effects of infection by larvae of Angiostrongylus cantonensis (Nematoda, Metastrongylidae) on the metabolism of the experimental intermediate host Biomphalaria glabrata. Exp Parasitol, 131(2): 143 - 147. DOI: 10.1016/j.exppara.2012.03.003

TuRkStanl. A., Hassan, A., Rabah, S. (2021): Effect of Larval Trematode Infection on the Nutritional Value of Nerita orbignyana Marine Snails. Int. J. Pharm. Phytopharm. Res., 11(2): In press. DOI: 10.51847/D2CHtkWEbS

ZвIKOWSKA, E. (2003): The effect of digenea larvae on calcium content in the shells of Lymnaea stagnalis (L.) individuals. J Parasitol, 89(1): 76 - 79. DOI: 10.1645/0022-3395(2003)089[0076:TEODLO]2.0.CO;2 